\title{
PEMARTABATAN WANITA DALAM NOVEL MATRIARK DARI PERSPEKTIF FEMINIS OLEH CHERI REGISTER
}

\section{(Raising the Status of Women in Matriark from the Perspective of Cheri Register's Feminist Theory)}

\author{
Norhayati Ab. Rahman \\ yati@um.edu.my \\ Jabatan Kesusasteraan Melayu, \\ Akademi Pengajian Melayu, Universiti Malaya.
}

Published on: 9 June 2020

To cite: Norhayati Ab. Rahman. (2020). Pemartabatan Wanita dalam Novel Matriark dari Perspektif Feminis oleh Cheri Register. Malay Literature, 33(1), 99-122.

\begin{abstract}
Abstrak
Makalah ini bertolak daripada kesedaran bahawa karya sastera oleh pengarang lelaki sering menggambarkan imej wanita yang stereotaip, pengalaman wanita dipinggirkan, suara wanita dibisukan dan bentuk paparan yang hanya menyerlahkan dan tertumpu pada lelaki. Oleh itu, makalah ini meneliti novel Matriark oleh Samsiah Mohd. Noor, menggunakan lima prinsip teori feminis oleh Cheri Register, iaitu teks sebagai forum membicarakan soal wanita, membantu mewujudkan persefahaman budaya wanita-lelaki, menyediakan peranan contoh, memupuk semangat persaudaraan wanita dan menimbulkan kesedaran kepada khalayak. Melalui aplikasi setiap prinsip tersebut, didapati wanita mempunyai pengalaman, suara, keinginan, wawasan, dan budaya mereka sendiri. Analisis terhadap novel Matriark dari perspektif teori feminis oleh Cheri Register membuktikan bahawa pengarang memartabatkan kedudukan wanita melalui pemaparan pengalaman, suara, hasrat, cita-cita, dan budaya mereka sendiri.
\end{abstract}

Kata kunci: Pengarang wanita, martabat wanita, teori feminis

(C) Dewan Bahasa dan Pustaka. 2020. This work is licensed under the term of the Creative Commons Attribution (CC BY) (http://creative commons.org/licenses/by/4.0/) 


\begin{abstract}
This article is based on the realization that literary works by men often depict stereotypical images of women, while women's experiences are sidelined, women's voices muted and depictions merely highlight and focus on men. The true characteristics of women can only be brought forth by studying texts produced by women writers. Therefore, this study takes a detailed look at Samsiah Mohd. Noor's novel, Matriark (2018), using the five principles of Cheri Register's feminist theory - the text as a forum for women, helping to achieve cultural androgyny, providing role models, promote sisterhood and augment consciousness-raising. Through the application of these principles, it is found that women have their own experiences, voices, desires, visions, and culture. The analysis of the novel Matriark from the perspective of Cheri Register's feminist theory proves that the writer raises the status of women through the depiction of their own experiences, voices, aspirations, ambitions and culture.
\end{abstract}

Keywords: Women writers, women's status, feminist theory

\title{
PENDAHULUAN
}

Pemartabatan wanita merujuk proses atau usaha mempertingkatkan kedudukan taraf wanita pada mata masyarakat. Pemartabatan berasal daripada kata dasar "martabat" yang bermaksud kedudukan individu pada mata masyarakat, darjat, pangkat, tingkat (Kamus Dewan, 1993, p. 803). Proses mempertingkatkan kedudukan wanita termasuklah tindakan meninggikan kedudukan wanita melalui pendidikan, kesedaran, literasi dan latihan. Pemartabatan wanita merupakan usaha untuk melengkapkan diri dan membolehkan kaum wanita membuat keputusan dan menentukan kehidupan melalui pelbagai permasalahan dalam masyarakat. Karya sastera yang digunakan sebagai data penelitian ialah novel Matriark (2018) oleh Samsiah Mohd. Noor, dengan menggunakan teori feminis oleh Cheri Register. Matriark merupakan karya terbaharu penulis wanita prolifik, Samsiah Mohd. Noor yang telah menghasilkan lebih 20 buah novel terkenal sebelumnya. Antara novel beliau termasuklah Sindora (1990), Bebunga Lalang (1991), Anom Suraya (1992), Selimut Malam (1993), Anggerik Kota (1994), Tangisan Bulan Madu (1995), Sangkar (1995), Tangisan Bulan Madu 2 (1999), Sebening Langit Senja (2002), Tangisan Bulan Madu 3 (2002), dan Tangisan Bulan Madu 4 (2003) dan Sejernih Lazuardi (2005). 
Judul novel Matriark itu sendiri membayangi subjek yang dipaparkan dalam novel ini, iaitu istilah berasal daripada perkataan matriarchy yang merujuk suatu masyarakat atau kelompok yang dipimpin oleh wanita. Secara khusus, matriark atau matriarch merujuk kepada "a form of society in which mothers are leaders and operate a women's decent line" (Humm, 1989, p.132). Masyarakat berfahaman matriarki meletakkan ibu sebagai pemimpin dan berperanan sebagai garis keturunan wanita. Pemikiran matriarki mengandaikan bahawa kekuatan dan tenaga keibuan serta cinta ibu sebagai satu bentuk kekuatan yang padu secara sosial. Engles dalam bukunya The Origin of the Family (1884) menyatakan bahawa konsep matriarki wujud terlebih dahulu sebelum patriarki bagi menggambarkan kekuatan wanita. Novel setebal 400 halaman ini memaparkan subjek kepimpinan wanita atau dominasi wanita, matriark, dalam sebuah organisasi kecil, iaitu pusat penempatan anak-anak yatim, miskin dan gelandangan yang tidak mempunyai rumah. Pusat penempatan bernama Teratak Aisyah dikendalikan oleh wanita bernama Aisyah. Pusat ini bukan sahaja menyediakan rumah tumpangan percuma, malah makanan, dan mendidik anak-anak malang dengan nilai-nilai agama dan sahsiah dengan tujuan untuk menjadikan mereka nanti sebagai manusia yang berguna kepada agama, bangsa dan negara. Pada masa yang sama Aisyah yang mewarisi teratak dan tanah daripada ibu angkatnya, Siti Naemah, berdepan dengan gangguan pihak penguat kuasa Kompeni Bandar yang bertindak menghalau penduduk Kampung Sempadan dengan alasan mereka menduduki tanah kerajaan secara tidak sah. Siti Aishah dengan bantuan penduduk kampung berusaha membuktikan bahawa mereka ialah pewaris sah kepada satu-satunya kampung Melayu yang masih wujud di tengah-tengah kepesatan pembangunan kota raya. Setelah berdepan dengan pelbagai cabaran, wanita tersebut akhirnya dapat merungkai permasalahan yang dihadapi dan menemui jalan keluar dengan dibantu oleh watak-watak lelaki yang bersefahaman dengan mereka. Menerusi naratif ini, Aisyah digambarkan sebagai matriark yang menjadi pemimpin kepada kelompok anak-anak gelandangan dan penduduk di Kampung Sempadan yang terletak di tengah-tengah kota Kuala Lumpur dan diasak oleh pembangunan serta tindakan kapitalisme. Matriark ialah sebuah kritikan sosial yang disalurkan melalui paparan perjuangan hidup masyarakat Melayu di kota raya Kuala Lumpur. Sorotan daripada perspektif yang jarang diberikan perhatian, iaitu dari kaca mata kehidupan golongan masyarakat bawahan dan gelandangan yang berjuang untuk hidup di tanah air mereka sendiri, sedangkan pada 
masa yang sama diperlihatkan golongan pendatang dapat hidup dengan senang-lenang dan mewah.

\section{PERSPEKTIF FEMINIS}

Mengikut kajian para pengkritik feminis, karya sastera yang dihasilkan oleh pengarang lelaki cenderung menggambarkan wanita dengan imej yang stereotaip, pengalaman wanita dipinggirkan, suara wanita dibisukan dan bentuk-bentuk paparan yang hanya menyerlahkan atau tertumpu pada lelaki (male-centredness). Dengan perkataan lain, wanita telah dijadikan objek dalam perbicaraan lelaki dengan berbagai-bagai cara dan matlamat. Wanita juga telah dijadikan sebagai seribu satu pembayang maksud untuk menyampaikan makna tersurat dan tersirat dalam pemikiran lelaki. ${ }^{1}$ Ellmann dalam Thinking about Women (1968) menyatakan pengarang lelaki menyerlahkan imej wanita sebagai tanpa bentuk, pasif, tidak stabil, terkongkong, mengharap, materialistik, spiritual, tidak rasional, patuh. Oleh itu, wanita dikatakan tidak memperoleh sebarang faedah daripada karya tersebut kerana pengalaman sebenar wanita tidak diketengahkan. Sebaliknya, paparan hanya menunjukkan bahawa wanita masih berada dalam kumpulan bisu dan sekali gus menyerlahkan yang disebut sebagai dominasi lelaki, dan penyerahan oleh wanita. Sebaliknya sifat-sifat yang tertumpu pada wanita hanya akan dapat diketengahkan dengan mengkaji teks yang dihasilkan oleh pengarang wanita. Maka, hal ini merupakan satu permasalahan yang perlu dirungkai, iaitu dengan cara mengalih tumpuan pengkaji kepada penulisan oleh wanita tentang wanita. Kajian perlu dilakukan terhadap teks yang dihasilkan oleh pengarang wanita bagi mencari keseimbangan antara gambaran pengarang lelaki dan wanita tentang wanita. Wanita dilihat sebagai pihak yang paling wajar dan berwibawa untuk berbicara tentang untung nasib mereka. Gambaran imej stereotaip wanita oleh pengarang lelaki, antaranya dapat dilihat melalui novel Salina (1961) oleh A. Samad Said. Melalui novel ini pengarang memaparkan imej wanita, iaitu Salina sebagai wanita yang pasif, tidak stabil, materialistik, tidak rasional, dan patuh, iaitu sebahagian besar daripada ciri-ciri stereotaip wanita. Dengan sifat-sifat negatif tersebut, watak Salina digambarkan selamanya terpenjara dalam kehidupan gelap (sebagai pelacur) dan penderitaan tiada berpenghujung. Gambaran yang hampir sama juga boleh ditemui pada watak Fatmah dalam novel Ta' Ada Jalan Keluar (1962) oleh Suratman Markasan, yang terperangkap dalam kehidupan gelap (pelacur) tanpa dapat membebaskan diri buat selamalamanya. Begitu juga dengan gambaran yang diberikan terhadap watak 
Seha dalam novel Ranjau Sepanjang Jalan (1966) oleh Shahnon Ahmad, yang menampakkan tahap kebergantungan wanita terhadap lelaki yang sangat tinggi. Tahap kebergantungan tinggi tersebut menyebabkan wanita menjadi tidak waras setelah kehilangan lelaki (suami) dalam hidupnya. Hal yang sama dapat dikesan pada watak Hayati dalam novel Bila Hujan Malam (1978) oleh Azizi Abdullah yang memaparkan pemerian wanita sebagai objek seks melibatkan penggunaan pil atau ubat perangsang untuk tujuan perkosaan. Pada akhirnya wanita yang terperangkap dalam kedurjanaan watak lelaki tersebut bertindak membunuh diri, yang membayangkan ikhtiar jalan keluar diambil secara salah. Paparan watak Salina, Fatmah, Jeha dan Hayati adalah antara ribuan contoh gambaran watak wanita malang yang tidak dimerdekakan atau dimartabatkan oleh pengarang lelaki dalam naratif mereka.

Sehubungan itu, kehadiran penulis wanita dalam sastera dilihat sebagai usaha untuk mengubah corak pelukisan wanita yang digarap oleh pengarang lelaki. Mereka sedar akan perlunya wanita supaya tampil memaparkan sendiri pengalaman hidup mereka untuk dibaca. Sebahagian mereka tidak ingin lagi melihat diri wanita dilukis dan diwarnakan secara tidak adil oleh pengarang lelaki. Oleh itu, timbul kesedaran dalam kalangan pengarang untuk tampil bukan hanya sebagai pembaca malah sebagai pengarang, pengeluar, penghasil dan juga sebagai pengkritik. Kajian terhadap karya sastera yang dihasilkan oleh pengarang wanita dilakukan bagi membuktikan wanita mempunyai imej, pengalaman, suara, keinginan, wawasan, bahasa dan budaya mereka sendiri. Sifat-sifat tertumpu kepada wanita (womencentredness) ini hanya dapat diketengahkan dengan mengkaji teks-teks yang dihasilkan oleh pengarang wanita.

Kajian terhadap karya pengarang wanita boleh dilakukan dengan menggunakan beberapa pendekatan atau teori feminisme, seperti Teori Ginokritik gagasan Elaine Showalter dan pendekatan feminis oleh Cheri Register. Walau bagaimanapun dalam penulisan makalah ini, pendekatan yang lebih sesuai untuk melihat rakaman dunia wanita dalam Matriark ialah pendekatan feminisme oleh Cheri Register, yang diguna pakai untuk membicarakan ciri-ciri karya sastera bercorak feminis. Menurut Cheri Register (1989, pp.1-27), beberapa ciri penting yang harus ada dalam sesebuah karya sastera bercirikan feminis ialah karya yang memenuhi lima prinsip berikut: 
(1) Sebagai forum membicarakan soal wanita (serve as a forum for women).

(2) Membantu mewujudkan persefahaman budaya wanita-lelaki (help to achieve cultural and androgyny).

(3) Menyediakan peranan contoh (provide role-models).

(4) Memupuk semangat persaudaraan wanita (promote sisterhood).

(5) Menimbulkan kesedaran kepada khalayak (augments consciousnessrising).

\section{SEBAGAI FORUM MEMBICARAKAN SOAL WANITA}

Prinsip pertama yang ditekankan oleh Register bagi sesebuah karya sastera untuk dapat dikategorikan sebagai karya feminis ialah karya itu dapat menjadi forum (tempat perbincangan secara terbuka) bagi wanita dengan cara mendedahkan pengalaman hidup dan nilai jati diri secara jujur mengikut perspektif wanita. Pendedahan tentang kehidupan sebenar wanita tersebut tidak lagi mengikut garis panduan dan tanggapan lelaki, supaya pembaca dapat memahami apa yang dialami dan dideritai oleh golongan wanita. Pendedahan tentang kehidupan sebenar wanita juga akan dapat mengubah pandangan negatif sesetengah masyarakat, khususnya kaum lelaki terhadap wanita. Gerda Lerner (1979) menjelaskan bahawa bagi memahami budaya wanita adalah penting untuk memeriksa pengalaman wanita dalam konteks mereka sendiri. Hal ini memandangkan pengalaman wanita merupakan aspek penting yang boleh dilihat dalam budaya wanita, termasuk dalam hasil penulisan wanita.

Melalui novel Matriark, Samsiah Mohd. Nor mengetengahkan pelbagai bentuk pengalaman dunia wanita dalam ruang yang bebas dan identiti yang terbuka serta rencam. Berdasarkan watak-watak wanita dalam novelnya, pengarang didapati tidak lagi mengaitkan wanita dengan peranan domestik semata-mata. Sebaliknya menampilkan watak wanita yang berperanan penting dalam kelompok masyarakat yang diwakilinya. Pertama, Aisyah digambarkan sebagai pemilik rumah tumpangan yang membantu anak-anak yatim, miskin dan anak gelandangan. Dia menggerakkan usaha dengan memanfaatkan harta warisannya (termasuk rumah sewa enam pintu) bagi menyediakan rumah tumpangan dan makan minum kepada anak-anak malang yang memerlukan bantuan. Usaha tersebut dilakukan dengan ikhlas demi untuk melihat anak-anak malang tersebut menjadi orang yang berguna kepada agama, bangsa dan negara. Antara anak yang pernah mendapat didikan awal di Teratak Aisyah di bawah kendalian Siti Naemah ialah Akasyah Benyamin 
yang kini telah menjadi seorang peguam. Sementelah pula Aisyah menjaga amanah daripada Siti Naemah untuk meneruskan legasi teratak tersebut. Aisyah berusaha untuk mempertahankannya seperti yang diperlihatkan pada petikan novel berikut:

\begin{abstract}
"Tanah Aisyah satu ekar. Arwah Siti Naemah dulu membina enam pintu rumah sewa di sekitarnya. Diberi sewa sampai sekarang, maka duit sewa itulah dapat menampung membeli beras dan keperluan dapur untuk anak-anak gelandangan. Kerana itulah Aisyah sayang sangat tanah warisan itu."
\end{abstract}

(2018, p. 28)

Petikan di atas memperlihatkan usaha Aisyah memperuntukkan seluruh harta warisan dan kehidupannya untuk membantu anak-anak miskin. Rumah pusaka dan pengalaman Aisyah yang diwarisi daripada ibu mentuanya, Siti Naemah, dilaksanakan dengan penuh rasa tanggungjawab dan amanah.

Kedua, Aisyah dicitrakan sebagai wanita berani dalam mengetuai penentangan terhadap pihak pemaju yang datang untuk menghalau mereka dari tanah yang diwarisinya sejak zaman-berzaman di Kampung Sempadan. Ketika berdepan dengan pasukan pekerja pemaju yang mendesak mereka untuk berpindah, Aisyah menjadi wanita yang cukup berani dan berada di barisan paling hadapan untuk mempertahankan haknya. Keberanian dan kelantangan suara dan pendirian Aisyah mempertahankan haknya dan hak penduduk kampung, dapat dilihat daripada cara dan keyakinannya ketika berhujah dengan pekerja Kompeni Bandar yang datang untuk menghalau mereka, seperti gambaran berikut:

"Nenek moyang mak aku yang buka rumah ini masa Kuala Lumpur
penuh berlumpur. Masa tu orang-orang yang cuba nak menghalau
aku ni belum ada. Mereka datang dari mana senang-senang nak halau
aku! Tanah ni moyang aku yang punya. Mak aku yang bernama Siti
Naemah binti Abdullah. Dia jadi saksi. Nama dia tertera pada geran,
tapi geran kami, puak-puak kau orang simpan kat pejabat tanah, Kau
orang sorokkan. Mereka tak hendak bagi pada kami. Padahal kamilah
penduduk di sini. Kau jangan lupa, keturunan kami yang buka tanah
belantara ini. Kau jangan buat-buat lupa" herdik Aisyah lagi. Suara di
belakang bersorak menyokong hujah Aisyah.

(2018, p. 20-21) 
Keyakinan dan keberanian Aisyah "melawan" kata-kata pekerja Kompeni Bandar mendapat sokongan dan sorakan daripada penduduk kampung lain di belakangnya seperti yang digambarkan dalam petikan di atas. Penentangan daripada Aisyah akhirnya menyebabkan para pekerja kompeni terpaksa beredar dari kawasan tersebut dan gagal menghalau penduduk Kampung Sempadan dari tanah mereka. Perjuangan menentang pihak pemaju yang cuba menghalau penduduk di kampung tersebut "diketuai" oleh Aisyah dan para penduduk Kampung Sempadan, sebuah perkampungan Melayu di tengah-tengah kota raya. Malah ketika jentolak dihalakan untuk meroboh rumah yang menempatkan anak-anak malang jagaannya, Aisyah dengan tangkas dan berani melompat serta berdiri betul-betul di depan jentolak sehingga pemandunya tidak berani meneruskan kerja-kerja perobohan. Aishah tampil sebagai "hero" yang berjuang habis-habisan menentang pihak kompeni yang ingin menghalau mereka dari kampung tersebut bagi tujuan membina bangunan komersial pencakar langit dan kondominium moden. Ketika penduduk kampung lain sudah hampir berputus harap dan mahu mengalah, Aishah bangkit sebagai "pejuang" bagi mempertahankan tanah air mereka daripada pencerobohan pihak luar yang menggunakan dokumen palsu.

Ketiga, Aisyah dicitrakan sebagai seorang wanita gigih dan tabah dalam mengharungi cabaran hidup semenjak zaman kanak-kanak di kampung apabila ibunya diceraikan oleh ayahnya sebelum melahirkannya. Sejak lahir dia tidak kenal ayahnya kerana ibunya, Jamilah, berkahwin dengan ayahnya tanpa persetujuan pihak keluarga ayahnya. Ibunya kemudian telah diceraikan oleh ayahnya tanpa mengetahui isterinya ketika itu sedang mengandung. Lahir tanpa ayah dan membesar dengan nenek di kampung, menjadikan perjalanan hidup Aisyah penuh liku, sebelum diarahkan oleh neneknya ke Kuala Lumpur dengan misi menjejaki ayah kandungnya. Pada usia awal remaja, dia telah sampai dan tinggal di rumah ayahnya selama dua tahun tanpa mengetahui bahawa itulah ayahnya dan ayahnya juga tidak mengetahui dia anaknya lantaran kerja jahat adik ibu tirinya. Apabila dia dihalau dari rumah tersebut, dia terlibat dengan pelbagai masalah sosial, sehingga diperkosa di jalanan dan dicampak di kawasan sampah, sebelum dijumpai dan dikutip oleh Siti Naemah serta dibesarkannya dengan penuh kasih sayang di Kampung Sempadan. Siti Naemah menjadi ibu angkatnya, kemudian menjadi mentuanya apabila dia berkahwin dengan Muhd Abduh, anak tunggal Siti Naemah. Aishah kemudian menjadi orang kepercayaan Siti Naemah untuk meneruskan legasinya untuk menjadikan Teratak Aisyah 
sebagai sebuah "madrasah" bagi anak-anak malang di kota raya. Hanya pada penghujung cerita, baharu diketahuinya bahawa Tan Sri Raisudin, tokoh korporat yang berjaya, yang juga ayah kepada Raykal yang banyak membantu Teratak Aisyah dan kelompok gelandangan, ialah ayah kandungnya yang dicari selama ini.

Ketiga-tiga bentuk pengalaman wanita di atas memperlihatkan gambaran situasi sosioekonomi kelompok masyarakat Melayu golongan bawahan yang hidup di ibu kota Kuala Lumpur. Di tengah-tengah kemelut kehidupan masyarakat bawahan tersebut, pengarang menunjukkan peranan penting wanita untuk melaksanakan tanggungjawab sosial dan kemasyarakatan kepada anak bangsanya. Aisyah telah memperuntukkan harta warisannya dan seluruh kehidupannya bagi membantu anak-anak gelandangan dan anak miskin, supaya mereka mendapat ilmu dan kelak menjadi orang yang berguna kepada masyarakat. Dia tidak mahu melihat anak bangsanya yang bernasib malang itu menjadi sampah masyarakat. Dalam konteks ini, pengarang merakamkan pengalaman wanita yang cenderung berbakti kepada masyarakat, sekali gus berupaya mengangkat martabat kaum wanita pada mata masyarakat. Dengan mengetengahkan pengalaman wanita dalam bidang sosial dan kemasyarakatan telah membuktikan peranan wanita yang luas dan tidak terhad. Begitu juga dengan pengalaman wanita sebagai "pemimpin" kepada kelompok masyarakatnya, menunjukkan bahawa wanita bukan sahaja menempati peranan sfera peribadi yang terhad, sebaliknya ikut terbabit dalam sfera umum bagi memperjuangkan hak dan kedudukan masyarakat kampungnya. Malah pengalaman keperitan hidup yang dijalaninya sejak di kampung dan kemudian di bandar, menjadikan wanita tersebut lebih kuat semangat, lebih menghargai peluang dan harta dunia yang dimilikinya, sehingga mendorongnya membantu anak-anak gelandangan, anak yatim dan anak daripada keluarga miskin supaya kelak mereka menjadi anggota masyarakat yang berguna kepada agama, bangsa dan negara. Harapan tersebut telah direalisasikan apabila anak asuhan ibunya Siti Naemah, iaitu Akasyah Benyamin telah berjaya menjadi peguam terkenal. Benyamin akhirnya kembali ke Teratak Aisyah untuk berbakti kepada Aisyah dan penduduk kampung yang berdepan dengan cabaran pihak kompeni untuk menghalau mereka dari tanah dan kampung halaman mereka sendiri.

Pengalaman wanita yang diangkat dalam novel ini dapat dijadikan sebagai forum atau perbincangan dengan merujuk kepada pengalaman Aisyah sendiri dan pengalaman kawan-kawan pembantunya, iaitu Mak Ngah Arisah, Che Alang Rohawati dan Abby Che Mang, yang setia bersama- 
sama membantu Aisyah menguruskan anak-anak gelandangan di Teratak Aisyah (terutama ketika Aisyah sesekali turut membantu suaminya di gerai buah). Dalam situasi serba kekurangan itulah mereka hidup bersama-sama seadanya dan saling melengkapi. Kebersamaan antara sesama mereka mendedahkan apa yang disebut Firestone sebagai "the female culture of emotion, intuition, love, personal relationship" (Humm,1989, p.42). Melalui novel ini, pengarang memperlihatkan para wanita mendepani pengalaman hidup yang sukar dan terhimpit, tetapi mereka tampil dengan hasrat, emosi, kecintaan dan hubungan baik antara mereka, untuk berbakti kepada anakanak gelandangan dan anak miskin. Naluri kewanitaan yang halus dan peka, menyebabkan mereka menganggap dan mengasihi anak-anak malang tersebut seperti anak kandung mereka sendiri.

Selain itu, pengarang juga membentangkan pengalaman wanita berhubungan dengan lelaki melalui watak Ruqyah, iaitu isteri Tan Sri Raisudin dan ibu kandung Raykal. Ruqyah dikahwini oleh Raisudin selepas perceraiannya dengan Jamilah. Selain cantik, Ruqyah juga wanita berpendidikan. Namun begitu, kehidupannya banyak dipengaruhi oleh adiknya sendiri, Ucu Rohimah yang tinggal bersama-sama dengan mereka sekeluarga. Nasib Ruqyah menjadi malang kerana selepas jatuh sakit, kewarasan ingatannya terjejas. Dia akhirnya menjadi wanita yang murung dan terkurung di rumah sendiri. Ruqyah yang berasa sangat kesepian di rumah, kerana anak dan suami yang sering sibuk dan tiada di rumah. Beberapa kali dia cuba untuk keluar dari "penjara" mewah yang mengurungnya di Orchard Heights. Sebagai anak, Haykal sendiri sering berasa sedih dan hiba dengan keadaan ibunya yang sentiasa terkurung di kamarnya. Ruqyah akhirnya berjaya meloloskan dirinya keluar dari rumah ketika pembantu rumah mereka leka berkebun dan pintu pagar kecil halaman rumah mereka terlupa dikunci. Ruqyah keluar dari rumah mengikut arah kakinya dan hilang selama lima hari, terperangkap dalam banjir kilat di bawah jambatan kawasan gelandangan dalam keadaan lemah tidak bermaya dan diselamatkan oleh anak-anak gelandangan sebelum dihantar ke rumah Aisyah. Peristiwa kehilangan Ruqyah menyedarkan suaminya, dan adiknya, Ucu Rahimah tentang betapa selama ini mereka tidak melayaninya dengan baik. Setelah itu, Ruqyah mendapat lebih perhatian dan kasih sayang daripada keluarganya, termasuk pertemuannya dengan anak tirinya, Raihana (Aisyah) yang sering kali muncul dalam mimpinya.

Pengalaman buruk wanita juga dipaparkan oleh pengarang melalui watak Jamilah, perempuan kampung yang dikahwini atas dasar cinta oleh 
Raisudin. Namun begitu, perkahwinan mereka tidak diterima oleh keluarga Raisudin terutama bapa Raisudin, iaitu Atuk Yusof. Beliau tidak boleh menerima kenyataan bahawa anak lelaki terpelajar kebanggaannya di seluruh kampung, yang belajar cemerlang hingga ke luar negara, akhirnya jatuh hati dan berkahwin dengan perempuan kampung tidak berpendidikan. Kisah duka Jamilah beberapa kali muncul dalam ingatan nenek Haykal, antaranya seperti yang berikut:

Nenek Halijah diam seribu bahasa. Dia terkenang-kenang Jamilah, bekas menantunya yang tidak disukai Atuk Yusof. Budak perempuan itu baik, tetapi kerana tidak berpelajaran, tidak diterima Atuk Yusuf. Jamilah berkahwin juga dengan Raisudin, tetapi tidak lama jodoh mereka. Raisudin berjumpa orang baru dan Jamilah ditinggalkan.

(2018, p.239)

Petikan di atas memperlihatkan nasib malang wanita kampung yang tidak berpendidikan. Meskipun dikahwini atas dasar cinta, tetapi kerana tidak berpelajaran dia diceraikan begitu saja, dan nasib wanita malang tersebut tidak lagi dipedulikan. Selepas bercerai, Jamilah pulang ke kampungnya di Kuala Pahang bagi menjaga ibunya yang sakit. Setelah ibunya meninggal dunia, hidupnya sendirian, dalam keadaan daif dan mengalami gangguan kesihatan mental. Keperluan makan dan minumnya hanya atas ehsan orang kampung. Hajah Halijah sekeluarga tidak pernah tahu bahawa Jamilah mempunyai anak dengan Raisudin kerana ketika diceraikan suaminya tidak pernah tahu dia sedang hamil anak mereka. Mereka sekeluarga sangat terkejut apabila mengetahui bahawa mereka mempunyai seorang lagi cucu, daripada bekas isteri pertama anaknya. Namun begitu, pada penghujung cerita, Jamilah dipertemukan semula dengan anak kandungnya, Raihana, yang telah meninggalkannya sejak 20 tahun lalu, di samping pertemuan semula dengan bekas suami dan madunya, iaitu Ruqyah. Jamilah telah dibawa ke Kuala Lumpur oleh Aisyah dan diberikan kehidupan yang lebih baik bersama-sama anaknya di Teratak Aisyah.

Berdasarkan contoh pengalaman wanita seperti dikemukakan di atas, didapati wanita memiliki pelbagai pengalaman yang unik dan rencam, serta sebahagiannya tidak terlepas daripada permasalahan terutama ketika berhubungan dengan kaum lelaki. Jamilah dan Ruqyah misalnya, dilanda permasalahan hidup yang berpunca daripada hubungan mereka dengan lelaki yang sama, Raisudin. Pemaparan sedemikian merupakan sebahagian daripada 
pengalaman kaum wanita dalam masyarakat yang telah dijadikan ruang perbincangan atau forum oleh pengarang Samsiah bagi membincangkan pengalaman pahit manis kaum wanita dalam kehidupan berkeluarga dan bermasyarakat. Walau bagaimanapun, pengarang didapati telah menunjukkan cara kepada watak-watak wanitanya bagi membebaskan diri mereka daripada semua bentuk permasalahan yang wujud dalam sistem penandaan lelaki. Hal ini dilaksanakan dengan cara mengemukakan bentuk-bentuk pengalaman yang dilalui wanita dalam masyarakat, kemudian menyarankan jalan keluar bagi melepaskan diri wanita daripada terperangkap dalam belenggu pengalaman buruk mereka. Dalam konteks ini, ternyata pengarang menulis dengan berpaksikan wanita dan berusaha membawa wanitanya ke arah kehidupan impian (promised land) yang diharapkan oleh feminis.

\section{MEMBANTU MEWUJUDKAN PERSEFAHAMAN BUDAYA WANITA DAN LELAKI}

Menurut Register, sesebuah karya sastera feminis itu mestilah dapat membantu mewujudkan persefahaman tentang pengalaman lelaki dan wanita, iaitu dengan cara saling hormat-menghormati dan faham-memahami pendirian, pendapat dan sebagainya yang sesuai dengan fitrah kejadian masing-masing. Dengan persefahaman tersebut dapat melahirkan perasaan kemanusiaan yang lebih positif dalam menjamin kebahagiaan dan kesejahteraan hidup. Dengan perkataan lain, karya feminis tidak seharusnya memupuk budaya tidak sihat seperti menganjurkan sikap antijantina yang berbeza. Sebaliknya perlu berperanan memupuk persefahaman tentang pengalaman lelaki dan wanita ke arah kehidupan berkeluarga dan bermasyarakat yang lebih sejahtera serta harmoni. Gambaran tersebut dilukiskan oleh pengarang melalui watak Aishah dan Wan Abduh, suaminya yang pendiam tetapi amat baik hati dan memahami tugas Aisyah sebagai pemegang amanah ibunya untuk meneruskan kelangsungan fungsi Teratak Aisyah. Begitu juga dengan persefahaman antara Aisyah dan Abang Hassan, penduduk Kampung Sempadan yang sentiasa memahami dan memberikan sokongan kepada kegiatan kebajikan dan kemasyarakatan Aisyah di kampung tersebut. Naratif ini banyak memberikan tumpuan kepada hubungan antara Aisyah dan Abang Hassan, iaitu lelaki yang paling dihormati di kampung tersebut kerana usianya yang paling tua antara mereka. Rumahnya berselang lima buah rumah dengan rumah Aisyah dan dia amat memahami serta menghormati pendirian Aisyah, seperti gambaran ini: 
Dia tahu Aisyah paling berkeras tidak akan tinggalkan kawasan rumahnya. Di tapak tanahnya itu, telah diwakafkan secara lisan untuk dibangunkan sebuah madrasah. Dan sekarang di rumahnya itu, dia membela anak-anak gelandangan yang bersepah di sekeliling kota. Tiketnya hanya keikhlasan kerana Allah. Dia mewarisi kerja amal Siti Naemah dulu. Bukan Abang Hassan tidak kenal arwah Naemah. Wanita kental yang berhati emas. Sekarang sifat itu jatuh pula pada Aisyah ...

(2018. pp. 30-31)

Pemaparan di atas menunjukkan keprihatinan dan kefahaman Abang Hassan terhadap sifat dan sikap Aisyah yang tegas dan keras dalam mempertahankan haknya, demi untuk memberikan kehidupan lebih baik kepada anak-anak gelandangan. Malah dia menganggap bahawa menjaga anak-anak gelandangan tersebut tanggungjawab mereka semua. Selama hidup di kampung tersebut, Abang Hassan menyaksikan sendiri anak-anak terbiar, anak terbuang, dan anak gelandangan dikutip serta dibela oleh Aisyah. Mereka bukan sahaja diberi makan, perlindungan, malah turut diberikan pendidikan agama seperti mengaji al-Quran dan bersolat. Dengan cara sedemikian, anak-anak tersebut tidak lagi merayau tidak menentu dan terjebak dengan maksiat serta menjadi sampah masyarakat. Aisyah telah memberikan peluang dan kehidupan baharu yang lebih cerah kepada mereka. Rasa kekaguman Abang Hassan terhadap Aisyah telah juga diungkapkan secara terbuka di depan ramai, "Abang Hassan kagum dengan kamu, Cah. Dalam keadaan kamu begini, kamu suami isteri gigih membantu anak-anak gelandangan. Kamu yang buat abang Hassan jadi kuat dan bersemangat untuk bertahan di tanah ini." (2018, p.32). Dalam konteks di atas, Abang Hassan tanpa segan mengakui bahawa selama ini dia menjadi kuat untuk tetap tinggal di kampung yang direbut oleh pemaju tersebut, kerana semangat yang ditunjukkan oleh Aisyah. Jika tidak kerana Aisyah, dia dan beberapa penduduk kampung telah mengalah kepada cabaran dan asakan ganas daripada pihak pemaju yang telah banyak kali datang menghalau mereka daripada Kampung Sempadan.

Melalui novel ini, pengarang memperlihatkan rasa persefahaman antara kedua-dua watak wanita dan lelaki tersebut. Mereka bukan sahaja berkongsi perasaan, pendirian dan rasa tanggungjawab yang sama terhadap anakanak gelandangan, malah saling memahami antara satu sama lain. Jalinan persefahaman tersebut membuka jalan untuk mereka saling membantu membina semangat dan kekuatan untuk berdepan dengan cabaran kehidupan di kampung tersebut. Gambaran terhadap perhubungan antara watak 
Aisyah dan Abang Hassan dalam novel ini, adalah antara contoh yang memperlihatkan adanya usaha pengarang untuk membantu mewujudkan rasa persefahaman antara lelaki dan wanita. Usaha ini selaras dengan gagasan teori feminis oleh Register yang mensyaratkan sesebuah karya feminis itu hendaklah bertujuan "help to achieve cultural androgyny" (1989, pp. 1-27). Persefahaman tersebut telah dikesan pada watak Aisyah dan Abang Hassan, di samping diperlihatkan juga melalui watak anak muda, iaitu Raykal dan Karmila Kasha yang berganding bahu membantu masyarakat gelandangan serta penduduk Kampung Sempadan. Meskipun lahir dalam keluarga yang kaya raya sebagai anak tokoh korporat yang berjaya dan hidup dalam kemewahan, Raykal amat prihatin dengan nasib malang kelompok gelandangan dan anak-anak miskin yang terbiar. Begitu juga dengan Karmila Kasha dan rakan-rakan mereka banyak membantu para gelandangan dari segi agihan makanan, pakaian, kewangan dan tenaga. Malah Raykal juga berusaha memasukkan Fahimi, iaitu anak pasangan yang hidup di bawah jambatan di Ampang Pecah ke sekolah. Teman Raykal, Karmila Kasha turut berperanan mengangkat dan mengetengahkan permasalahan para gelandangan dan Teratak Aisyah yang sering diganggu oleh pihak pemaju dalam siaran Blog KK yang dikendalikannya secara senyap. Pendedahan tersebut telah menarik perhatian dan menyedarkan banyak pihak sehingga mereka tampil membantu para gelandangan yang hidup di bawah jambatan. Tulisan Karmila Kasha tentang Teratak Aisyah pula menarik perhatian seorang peguam terkenal untuk tampil membantu penduduk Kampung Sempadan bagi mempertahankan hak mereka daripada gangguan pemaju.

Berdasarkan perbincangan teks di atas, memperlihatkan pengarang berpendapat bahawa persefahaman antara wanita dan lelaki merupakan elemen penting dalam kehidupan, yang berupaya menjana kejayaan dan kesejahteraan kehidupan. Pemaparan sedemikian adalah sesuai dan selaras dengan pandangan Register yang menyarankan karya sastera feminis seharusnya dapat membantu mewujudkan persefahaman budaya wanitalelaki (help to achieve cultural and androgyny) dalam masyarakat. Walaupun pemikiran feminis menekankan kemandirian wanita dalam setiap aspek kehidupan, namun Register melihat dari perspektif yang berbeza daripada fahaman feminis radikal yang melihat bahawa wanita-lelaki berada dalam suatu permusuhan yang berkekalan. Sebaliknya prinsip Register lebih terbuka, menyarankan karya sastera feminis dijana bagi membantu mewujudkan persefahaman antara pengalaman lelaki dan wanita, iaitu dengan cara saling menghormati dan memahami pendirian, pendapat dan sebagainya yang sesuai dengan fitrah kejadian masing-masing. 


\section{MENYEDIAKAN PERANAN CONTOH}

Menurut Register, watak-watak wanita yang ditonjolkan dalam karya haruslah menjadi suri teladan (role model) untuk dicontohi, terutama berhubung dengan identiti wanita yang mempunyai self-actualizing, pandai berdikari (autonomous) dan tidak bergantung sepenuhnya kepada lelaki. Kegiatan wanita juga tidak harus dikongkong oleh tradisi yang dikuasai dan didominasi oleh lelaki sahaja. Hal ini ditegaskan oleh Register seperti berikut:

... a literary work should provide "role-models", instill a positive sense of feminine identity by portraying women who are "selfactualising", whose identities are not dependent on men.

$(1989$, p.20)

Dalam novel ini, pengarang menampilkan watak Aisyah sebagai suri teladan yang dapat dicontohi oleh khalayak pembaca. Aisyah digambarkan sebagai wanita yang gigih, dan bersifat tegas mempertahankan sesuatu keputusan dan haknya. Selain penduduk Kampung Sempadan yang mengaguminya, beliau juga dikagumi oleh anak-anak muda yang masih belajar di universiti seperti Haykal, Karmila Kasha dan rakan-rakan sebayanya. Kisah dan perjuangan hidup Aisyah daripada hidup terbuang sehingga menjadi orang yang berjasa kepada masyarakat bawahan, menjadi inspirasi kepada anak-anak muda. Malahan pesanan Aisyah kepada mereka sentiasa dijadikan sebagai semangat anak-anak muda untuk berjaya dalam hidup. Antara lain Aisyah berpesan;

"Jadikan kisah Mak Cah sebagai kekuatan. Sebagai semangat. Jangan
merintih. Jangan meminta. Hidup ialah perjuangan. Berjuang terus.
Masa ini bukan masa untuk bersedih atau berhiba. Kamu orang-orang
muda kena bangkit. Jadi orang-orang berilmu. Jadi orang hebat. Jadi
orang yang bertanggungjawab pada agama, bangsa dan negara."

(2018, p. 252)

Melalui petikan di atas, pengarang memperlihatkan peranan watak utamanya, Aisyah sebagai orang yang wajar dijadikan sebagai contoh untuk diteladani. Aisyah ditampilkan sebagai sosok yang berwawasan, beriltizam dan bermotivasi yang selayaknya dijadikan sebagai suri teladan oleh generasi muda di dalam dan di luar teks. Oleh itu, tidaklah hairan apabila Karmila Kasha dan Haykal serta rakan-rakan mengungkapkan frasa 
kekagumannya terhadap semangat perjuangan Aisyah. Di samping itu, sifat kebijaksanaan dan ketegasannya adalah perlu untuk mempertahankan sesuatu yang dianggap signifikan. Sebagai pewaris yang bertanggungjawab menjaga amanah ibu mertuanya, Siti Naemah, untuk menjadikan Teratak Aisyah sebagai "madrasah" bagi anak-anak bernasib malang. Kesungguhan, ketegasan dan keberanian Aisyah mempertahankan haknya dan anak-anak malang jagaannya adalah sangat wajar dicontohi.

Selain itu, sikap tabah dan tidak mudah mengalah kepada apa-apa jua bentuk tekanan serta cabaran yang mendatang harus disemai dalam diri setiap wanita. Pandangan ini disampaikan pengarang melalui watak Aisyah. Meskipun beliau telah melalui perjalanan hidup yang sangat perit, diperkosa dan dibuang di tempat pembuangan sampah, tetapi beliau bangkit semula. Tekanan hebat daripada pihak pemaju yang ingin menghalau mereka dari kampung sendiri, rumah yang ingin dirobohkan, dan masalah kekurangan dana untuk membiayai kos penampungan anak-anak gelandangan di terataknya, tidak pernah melemahkan semangat Aisyah. Dia yakin dan percaya bahawa dengan usaha, tawakal dan doa, segalanya akan berakhir dengan baik. Watak Aisyah dengan sifat-sifatnya sebagai wanita yang tabah, cekal, tegas dan berani memperjuangkan hak demi membela nasib anakanak gelandangan, serta mempamerkan ciri-ciri wanita Muslimah sejati yang sedia mewakafkan seluruh harta dan hidupnya kerana Allah, wajar diteladani oleh khalayak pembaca, khususnya wanita.

Melalui strategi naratifnya, pengarang memperlihatkan bahawa pada hari ini wanita tidak lagi hanya ditempatkan dalam ruang peribadi. Melalui watak Aisyah pengarang menunjukkan bahawa wanita yang bersuami juga tidak lagi bergantung pada suami sepenuhnya. Tahap kebergantungan wanita kepada lelaki direndahkan, apabila pengarang memaparkan Aisyah berkahwin dengan Wan Abduh yang perwatakan dan fikirannya tidak setegas dan secerdas Aisyah. Perkara ini diperlihatkan dalam petikan berikut:

"Dia tidak boleh harapkan Wan Abduh. Siti Naemah sudah berpesan, Wan Abduh tidak mampu. Walaupun dia lelaki tetapi jiwanya lembut sangat. Dia tidak kuat. Dia kurang perkasa. Siti Naemah berkata, Aisyah yang paling sesuai. Aisyah lambang wanita berjiwa kental. Kerana itu nama Aisyah yang terpampang pada geran pusaka miliknya. Aisyahlah yang akan menerajui Teratak Aisyah nanti."

(2018, p. 331) 
Penyataan di atas memperlihatkan kelebihan Aisyah berbanding suaminya, Wan Abduh dalam soal perjuangan yang ditinggalkan oleh Siti Naemah, ibu Wan Abduh. Malah Siti Naemah sendiri tidak mengharapkan anak lelakinya untuk mewarisi perjuangannya, sebaliknya meletakkan kepercayaan dan keyakinannya kepada Aisyah, menantunya. Dalam konteks ini menunjukkan pengarang memanfaatkan penulisan novel ini sebagai ruang untuk mendedahkan keinginan wanita bagi mencapai cita-cita dan wawasan sebagai individu yang berautonomi. Keupayaan dan pencapaian Aisyah dalam merealisasikan wasiat Siti Naemah, adalah berdasarkan kegigihan usaha dan perjuangannya. Dengan kata lain, pengarang menegaskan bahawa wanita boleh hidup berjaya tanpa lelaki, tetapi mereka tetap memerlukan lelaki untuk kesejahteraan dan kesempurnaan hidup seperti fitrah kejadian setiap makhluk. Oleh itu, meskipun naratif ini memberikan perhatian khusus kepada watak Aisyah (women-centred), namun watak Wan Abduh dilihat masih ditampilkan sesekali dalam cerita ini. Dia diperlihatkan sebagai seorang suami yang baik, bertanggungjawab dan turut membantu isterinya menguruskan Teratak Aisyah. Pendirian pengarang yang disalurkan dalam penggarapan novel ini sudah tentu selaras dengan tuntutan agama Islam dan nilai masyarakat Melayu di negara ini.

\section{MEMUPUK SEMANGAT PERSAUDARAAN WANITA}

Menurut Register, sesebuah karya sastera bersifat feminis perlu memupuk semangat persaudaraan sesama wanita atau dikenali sebagai sisterhood. Pemaparan sebegini adalah bertentangan dengan gambaran wanita yang stereotaip oleh pengarang lelaki. Wanita perlu digambarkan saling bekerjasama, memupuk dan menjalinkan persaudaraan serta mempunyai sikap saling memahami antara satu sama lain. Persaudaraan wanita disebut juga sebagai perkumpulan (sorority) wanita. Perkumpulan ini merangkumi gagasan dan pengalaman ikatan wanita, pengukuhan diri, identiti yang ditemui dalam pandangan yang berpusat kepada wanita serta tafsiran mengenai wanita. Persaudaraan wanita terbentuk berdasarkan kesedaran yang jelas bahawa semua wanita, tanpa mengira kelas, ras atau bangsa berkongsi permasalahan yang sama, iaitu patriarki (Humm, 1989, pp. 210-211). Persoalan ini sering kali diketengahkan oleh pengarang wanita dalam penulisan atas kesedaran terhadap sifat kebersamaan pengalaman wanita seluruhnya. Wanita melihat setiap wanita dalam masyarakat menghadapi pengalaman dan permasalahan yang hampir sama. Oleh itu, pengarang akan memetik dan menyaring 
sebahagian daripada pengalaman mereka sebagai sebahagian daripada peristiwa yang dilalui dan dirasai oleh wanita seluruhnya.

Gambaran sisterhood ini dikesan menerusi Matriark yang menampilkan kekuatan dan perpaduan wanita sebagai salah satu landasan penting yang mendasari pemikiran dan proses penciptaan karya sastera wanita. Ikatan persaudaraan wanita ini mendorong ke arah terbentuknya penyelesaian dalam pergelutan emosi yang membelenggu wanita. Menerusi novelnya, Samsiah mengangkat persoalan kekuatan perpaduan dan persaudaraan wanita melalui watak Aisyah, Mak Ngah Arisah, Che Alang Rohawati dan Abby Che Mang, yang setia bersama-sama membantu Aisyah menguruskan anak-anak gelandangan di Teratak Aisyah. Dalam situasi serba kekurangan dan berdepan dengan cabaran besar daripada pihak kompeni yang sentiasa menghalau mereka dari kampung tersebut, mereka tetap hidup bersama-sama seadanya dan saling melengkapi. Persaudaraan sesama mereka mendedahkan hal yang disebut Firestone sebagai sebahagian daripada budaya wanita terjalin dalam hubungan perasaan, naluri-keinginan, kasih sayang dan perhubungan peribadi (Humm, 1989, p.42). Melalui novel ini, pengarang memperlihatkan walaupun para wanita mendepani pengalaman hidup yang sukar dan terhimpit, tetapi mereka ditampilkan dengan hasrat, emosi, kecintaan dan hubungan baik antara mereka, untuk sama-sama berbakti kepada anak-anak gelandangan dan anak miskin. Naluri kewanitaan yang halus dan peka, menyebabkan mereka menganggap dan mengasihi anakanak malang tersebut seperti anak kandung mereka sendiri.

Aisyah dan Hamimah misalnya, dua wanita yang berhubung akrab dan berkongsi nilai, sikap dan tanggapan sama terhadap nilai penguasa yang dianggap menindas. Pengarang memperlihatkan kedua-dua wanita ini saling memahami antara satu sama lain dan sanggup pula untuk saling membantu. Aisyah digambarkan sebagai wanita yang penuh prihatin, kasih sayang dan rasa tanggungjawab terhadap sahabatnya, Hamimah. Gambaran tersebut dapat dilihat ketika gerai makanan tempat Hamimah berniaga untuk mencari rezeki telah dirobohkan oleh pihak kompeni. Hamimah menjadi panik dan menangis kesedihan mengenangkan nasib malangnya apabila gerai tempat dia mencari rezeki telah dirobohkan oleh pihak Kompeni Bandar pada bulan Ramadan. Aisyah yang berasa sangat simpati, memujuk dan memberikan nasihat kepada Hamimah supaya bersabar menerima ujian. Memahami keadaan Hamimah yang dilanda musibah, Aisyah memberi kelonggaran kepadanya untuk tidak membayar sewa rumahnya sehingga dia mempunyai wang, malah turut mengajak Hamimah anak-anaknya untuk makan di rumahnya bersama-sama anak-anak terataknya. 
"Kau berbuka di sini saja Imah, dengan budak-budak. Tak usah dikenang gerai kau yang dah roboh. Anggap saja tak ada rezeki. Allah nak ganti yang lebih baik." Pujuk Aisyah.Termakan pujukan, wajah Hamimah tenang sedikit."

(2018, p.164- 165)

Melalui petikan di atas, Aisyah yang memahami permasalahan yang dihadapi oleh Hamimah, telah memberikan sokongan moral dan bantuan kepada wanita yang berada dalam kesusahan tersebut, yang telah dianggap seperti saudaranya sendiri. Semangat persaudaraan wanita tersebut direalisasikan dalam kehidupan seharian mereka bersama-sama di Kampung Sempadan. Mereka mendepani tantangan daripada pihak Kompeni Bandar yang sering mengganggu, untuk menghalau mereka daripada tanah yang diduduki bagi tujuan kepentingan pihak mereka. Bagi Aisyah, masalah Hamimah telah menjadi sebahagian daripada permasalahannya.

Selain itu, pengarang juga memerihalkan ketika Aisyah menghadapi masalah kekurangan tenaga dalam pengurusan Teratak Aisyah, Aisyah dibantu oleh Mak Ngah Arisah, Che Alang Rohawati dan Abby Che Mang. Merekalah yang bersatu tenaga memberikan perkhidmatan secara percuma kepada Aisyah dengan membantu melakukan penyediaan makan minum kepada anak-anak gelandangan di Teratak Aisyah. Malah ketika mereka berdepan dengan permasalahan, Aisyah jugalah tempat mereka mengadu dan meminta pertolongan. Menurut teori feminis, ikatan persaudaraan wanita adalah penting untuk mendorong terbentuknya penyelesaian dalam pergelutan emosi yang membelenggu wanita. Hal ini terbukti apabila Aisyah akhirnya dapat membantu dan menyelesaikan permasalahan yang dihadapi para sahabatnya wanita dan begitu juga sebaliknya ketika Aisyah memerlukan pertolongan mereka.

Demikian semangat persaudaraan wanita yang dilakarkan dan dihidupkan pengarang melalui watak-watak wanita yang berkongsi impian dan harapan, penderitaan, kesedihan dan perjuangan akan mampu memartabatkan kedudukan wanita pada mata masyarakat. Melalui kaedah pemupukan semangat persaudaraan sesama wanita ini, membuktikan usaha pengarang wanita memanfaatkan penulisan mereka sebagai wahana yang menjadi sumber kekuatan, perpaduan dan persaudaraan wanita. Sekali gus membebaskan wanita daripada kongkongan permasalahan hidup serta meletakkan kedudukan wanita pada taraf yang lebih baik daripada sebelumnya. Penonjolan semangat persaudaraan sesama wanita dalam 
novel Matriark adalah amat penting bagi meletakkannya sebagai sebuah karya feminis. Novel ini selaras dengan gagasan teori feminis oleh Register yang mahukan pengarang wanita memupuk semangat persaudaraan sesama wanita. Pemaparan sebegini adalah penting bagi membuktikan bahawa corak penulisan wanita lazimnya bertujuan untuk memperlihatkan kekuatan wanita melalui rasa persaudaraan sesama wanita. Untuk memartabatkan kedudukan wanita dalam masyarakat, wanita perlu digambarkan memiliki sifat-sifat positif dengan bersikap saling bekerjasama, memupuk dan menjalinkan persaudaraan serta sikap saling memahami antara satu sama lain. Wanita diperlihatkan berkongsi pengalaman sesama mereka dan saling membantu antara satu sama lain. Dengan cara sedemikian, kedudukan wanita di mata masyarakat dapat diangkat dan dimartabatkan.

\section{MENIMBULKAN KESEDARAN KEPADA KHALAYAK}

Seterusnya menurut Register, sebuah karya feminis juga perlu menimbulkan kesedaran dengan adanya perkembangan kendiri wanita dan persepsi diri wanita terhadap cabaran yang datang dari luar. Kisah wanita yang berhadapan dengan segala rintangan dan cabaran menempuh kehidupan, sepatutnya dapat menimbulkan kesedaran dalam diri khalayak pembaca betapa wanita itu masih mampu berdiri tegak mengharungi segala cabaran yang mendatang. Antaranya dengan memaparkan pengalaman wanita di tempat kerja, penderaan atau pengalaman buruk wanita dalam rumah tangga dan pengalaman suka duka wanita secara keseluruhannya. Dengan pemaparan sedemikian, dapat menimbulkan kesedaran dan pengetahuan kepada khalayak pembaca agar lebih memahami penderitaan dan masalah kaum wanita, sekali gus memberikan kesedaran untuk mengambil langkahlangkah pencegahan untuk mengatasinya.

Dengan pemaparan kepelbagaian kisah dan pengalaman wanita melalui watak Aisyah, Hamimah, Jamilah, Ruqyah dan lain-lain dalam novel Matriark, pengarang didapati cuba menganjurkan kesedaran tertentu kepada khalayak pembacanya. Pertama, menimbulkan kesedaran supaya wanita tidak bersikap pasif dan mudah mengalah kepada cabaran hidup. Untuk tujuan tersebut, pengarang mengangkat pengalaman Aisyah bagi membuktikan bahawa sekiranya sekali kecundang dalam hidup, wanita tidak membiarkan diri selamanya terpenjara dalam kekalahan. Wanita perlu bangkit berjuang untuk mengubah kehidupan diri sendiri dan membantu orang lain, ke arah kehidupan yang lebih baik. Gagasan inilah yang diperlihatkan pada watak wanita bernama Aishah (nama asalnya Raihana). Ketika remaja, 
dia telah datang dari kampung di Kuala Pahang ke Kuala Lumpur untuk mencari ayah kandungnya, kemudian terlibat dengan masalah sosial. Setelah diselamatkan oleh Siti Naemah, Raihana tampil sebagai Aisyah dengan jiwa dan semangat baharu untuk mengubah dirinya menjadi manusia berguna. Aisyah diamanahkan oleh ibu angkat dan kemudian menjadi mentuanya, untuk menjaga dan meneruskan kerja-kerja kebajikan Siti Naemah. Atas kesedaran untuk berbakti, Aisyah menyambung legasi murni Siti Naemah, menjaga dan mengurus rumah kebajikan persendirian, yang memberikan tempat tinggal, makan minum, kasih sayang dan pendidikan kepada anakanak malang yang memerlukan bantuan. Walaupun Aisyah berdepan dengan cabaran besar apabila rumahnya dan rumah penduduk kampungnya dikatakan menduduki tanah secara tidak sah dan ingin dirobohkan oleh pihak pemaju. Geran tanah mereka disembunyikan di pejabat tanah dan mereka dihalau dari kampung yang telah diduduki sejak zaman moyang Siti Naemah. Namun begitu, berkat ketegasan, keberanian dan kesungguhan perjuangan Aisyah untuk mempertahankan rumah dan amanah yang dipertanggungjawabkan kepadanya, akhirnya mereka berjaya membuktikan bahawa tanah yang diduduki mereka mempunyai geran yang sah. Urusan Aisyah ini dipermudah pada akhir cerita, apabila dia dibantu oleh Akasyah Benyamin, seorang peguam terkenal yang pada zaman kanak-kanaknya antara penghuni rumah kebajikan yang dikendalikan oleh Siti Naemah, seperti pengakuannya:

"Sebelum saya berpeluang melanjutkan pelajaran ke universiti luar negara, di sinilah saya mula menimba ilmu. Teratak inilah universiti pertama saya yang mengajar nilai-nilai keinsanan yang tidak saya temui di mana-mana universiti yang saya pergi." Akasyah pecahkan rahsia yang selama ini hanya dia sahaja yang menyimpannya."

(2018, p. 390)

Pengakuan bekas penghuni Teratak Aisyah di atas memperlihatkan cebisan kejayaan visi dan misi Teratak Aisyah bagi membantu anak-anak malang, dan menjadikan mereka sebagai insan berguna kepada agama, bangsa dan negara seperti yang dihasratkan oleh pengasas asal teratak tersebut, Siti Naemah. Pemaparan kisah perjuangan Aisyah dan hasilnya yang diperlihatkan dalam novel ini, diharap dapat menimbulkan kesedaran kepada khalayak untuk berjuang bagi mendapatkan kehidupan yang lebih baik bagi diri sendiri dan juga orang lain.

Kedua, pemaparan sifat mulia dan terpuji pada diri Aisyah yang telah memberikan seluruh hidup dan hartanya untuk tujuan kebajikan bagi 
golongan yang malang dan lebih memerlukan, akan memberi inspirasi kepada khalayak untuk melakukan kebaikan dengan cara dan kemampuan tersendiri. Hal ini jelas kelihatan pada hasratnya untuk membina madrasah, seperti ungkapan di bawah:

\begin{abstract}
"Madrasah ini untuk anak-anak gelandangan. Bukan seperti madrasah biasa yang tumbuh di merata-rata. Madrasah ini ialah madrasah ihsan. Penuntut-penuntut ilmu di madrasah ini tidak akan dikenakan sebarang bayaran dan pengajar-pengajarnya ialah pengajar yang tidak menerima gaji. Mereka hanya akan menerima bonus. Bonus itu pun bukan diberikan pada masa ini, tetapi disimpan untuk bekalan kemudian ..."
\end{abstract}

(2018, p. 144)

Gambaran daripada petikan di atas menjelaskan tentang konsep madrasah yang ingin didirikan oleh Aisyah, khusus untuk anak-anak gelandangan, yang berbeza daripada madrasah biasa. Pembinaan yang sedang diusahakan itu merupakan sebahagian daripada amanah ibu mentuanya, Siti Naemah. Penubuhan madrasah ini merupakan suatu kebajikan yang sangat besar kesan dan pahalanya, dengan mewakafkan harta mereka ke jalan kebajikan, akan memberi inspirasi kepada khalayak pembaca.

Ketiga, dengan menimbulkan kesedaran terhadap perkembangan kendiri wanita dan persepsi wanita terhadap cabaran yang datang dalam hidup mereka. Pengalaman hidup Jamilah dan Ruqyah misalnya, dua wanita yang dikahwini oleh lelaki yang sama, iaitu Raisuddin, tetapi tidak diterima sebagai amanah dan tanggungjawab telah menjerumuskan hidup wanita dalam penderitaan.

Perkahwinan merupakan sebahagian daripada fitrah manusia dan berdasarkan fitrah itulah Allah SWT mencipta manusia. Perkahwinan juga merupakan hukum Allah (sunnatullah) yang berlaku di alam nyata, justeru Islam melarang umatnya menolak atau mengabaikan perkahwinan. Perkahwinan sepatutnya menjadi institusi yang membawa kesejahteraan dan kebahagiaan, tetapi sebaliknya jika gagal dikendalikan oleh lelaki. Dalam konteks ini, kegagalan lelaki memainkan peranan sebagai nakhoda rumahtangga dilihat sebagai satu asbab utama kepada pengalaman buruk wanita dalam institusi perkahwinan. Gambaran yang dipaparkan oleh pengarang ini merupakan rakaman realiti yang boleh menimbulkan kesedaran kepada pembaca untuk belajar daripada kesilapan Raisudin, yang leka mengejar harta dunia dan mengabaikan amanah serta tanggungjawab sebagai 
suami. Semua pemaparan yang diberikan pengarang melalui watak-watak ciptaannya dalam Matriark bukan sahaja dapat memberikan keseronokan semata-mata, malah lebih daripada itu dapat memberi kesedaran dan manfaat yang besar kepada khalayak pembaca, khususnya yang berhubung dengan pengalaman watak-watak wanitanya.

\section{KESIMPULAN}

Berdasarkan perbincangan di atas, dapatlah disimpulkan bahawa novel Matriark oleh Samsiah ialah sebuah novel yang boleh dikategorikan sebagai karya berunsur feminis, khususnya mengikut takrifan dan pendekatan feminis Register. Tema dan persoalan yang diangkat melalui novel ini adalah jelas ke arah mengangkat kedudukan dan martabat wanita melalui watak Aisyah, Hamimah, Karmila Kasha, Mak Ngah Arisah, Che Alang Rohawati dan Abby Che Mang. Melalui pengalaman kehidupan watak wanita yang bersifat pelbagai dan rencam jelas pengarang telah menjadikan teks ini sebagai suatu forum membicarakan soal wanita. Selain itu, wujudnya usaha ke arah persefahaman antara wanita-lelaki dalam novel ini melalui watak Aisyah dan Abang Hassan, Raykal dan Karmila Kasha yang memperlihatkan peranan pengarang bagi mewujudkan persefahaman budaya wanita-lelaki, selaras dengan gagasan teori feminis Register. Sementara penjanaan watak wanita yang bersemangat kental, tabah, cekal dan akhirnya berjaya dalam merealisasikan impian, secara tidak langsung sebagai contoh suri teladan kepada pembaca, selain melukiskan dan menyarankan rasa persaudaraan sesama wanita melalui watak-watak wanita ciptaannya.

Seterusnya, inti cerita yang digarapkan pengarang turut menekankan aspek penting berhubung dengan pengalaman dan keperluan wanita secara tidak langsung berupaya memberikan kesedaran kepada khalayak pembaca yang melengkapkan kesemua ciri-ciri Matriark sebagai sebuah karya berunsur feminis. Daripada hasil perbincangan berdasarkan teori feminis yang dikemukakan oleh Register di atas, jelas memperlihatkan kepentingan dan peranan novel Matriark ini dalam usaha untuk mengangkat dan memartabatkan kedudukan wanita pada mata masyarakat dari pelbagai sudut dan aspek. Sekali gus mengangkat teks ini sebagai sebuah karya yang harus dibaca, ditanggapi dan difahami sepenuhnya oleh para wanita. 


\section{NOTA}

1. Gambaran watak-watak wanita dalam karya yang dihasilkan oleh pengarang lelaki didorong oleh tiga perkara: Pertama, berlandaskan model atau contoh umum yang pernah dilihat atau dikenali. Kedua, berdasarkan produk keadaan sosial wanita dalam masyarakat itu sendiri. Ketiga, pelukisan watak sebagai simbol keinginan pengarang terhadap wanita yang dapat menghibur. Lihat Register, 1989, p.5.

\section{RUJUKAN}

A. Samad Said. (1961). Salina. Kuala Lumpur . Dewan Bahasa dan Pustaka.

Ellmann, Mary. (1968). Thinking about Women. London: MacMillan.

Engels, Friedrich . (1884 ; rpt . 1972 ). The Origin of the Family, Private Property, and the State . Trans . Robert Vernon . Intro by Evelyn Reed. New York: Pathfinder Press.

Humm, Maggie. (1989). The Dictionary of Feminist Theory. New York: Harvester Wheatsheaf.

Kamus Dewan. (1993). Kuala Lumpur: Dewan Bahasa dan Pustaka.

Lerner, Gerda. (1979). The Challenge of Women's History, in The Majority Finds It's Past: Placing the Women in History. New York: Oxford University Press.

Register, Cheri. (1989). American Feminist Literary Criticism: An Bibliografhical Introduction. Donovan, Josephine (Ed..), Feminist Literary Criticism: Explorations in Theory. Kentucky: The University Press of Kentucky.

Samsiah Mohd. Noor. (1991). Sindora. Kuala Lumpur: Creative Enterprise.

Samsiah Mohd. Noor. (1992). Anom Suraya. Kuala Lumpur: Creative Enterprise. Samsiah Mohd. Noor. (1993). Selimut Malam. Kuala Lumpur: Creative Enterprise. Samsiah Mohd. Noor. (1994). Anggerik Kota. Kuala Lumpur: Creative Enterprise. Samsiah Mohd. Noor. (1995). Tangisan Bulan Madu. Kuala Lumpur: Creative Enterprise.

Samsiah Mohd. Noor. (2002). Sebening Langit Senja. Batu Caves, Selangor: Diwangsa Publications \& Distributors.

Samsiah Mohd. Noor. (2002). Tangisan Bulan Madu 3. Bangi: Khalysa Publications \& Distributors.

Samsiah Mohd. Noor. (2003). Tangisan Bulan Madu 4. Bangi: Khalysa Publications \& Distributors.

Samsiah Mohd. Noor. (2005). Sejernih Lazuardi. Seri Kembangan: Citrakurnia Enterprise.

Samsiah Mohd. Noor. (2018). Matriark. Kuala Lumpur: Dewan Bahasa dan Pustaka.

Suratman Markasana. (1952). Ta’Ada Jalan Keluar. Singapore: Marican \& Sons.

Received: 20 April 2020

Accepted: 16 May 2020 